\title{
A new species of Brethesiamyia Maia (Diptera: Cecidomyiidae) from Colombia with description of immature forms
}

\author{
Esau Adenawer Ospina-Peñuela ${ }^{1,4}$; Carlos José Einicker Lamas ${ }^{2}$; Francisco Serna ${ }^{1,5}$ \& Maria Virginia Urso-Guimarães ${ }^{3}$
}

1 Universidad Nacional de Colombia (UNAL), Facultad de Ciencias Agrarias, Museo Entomológico (UNAB), Grupo Sistemática de Insectos Agronomía (SIA). Bogotá, Colombia.

2 Universidade de São Paulo (USP), Museu de Zoologia (MZUSP). São Paulo, SP, Brasil. ORCID: http://orcid.org/0000-0002-7750-590X. E-mail: einicker@usp.br

${ }^{3}$ Universidade Federal de São Carlos (UFSCAR), Centro de Ciências Humanas e Biológicas (CCHB), Departamento de Biologia (DBI0), Laboratório de Sistemática de Diptera. Sorocaba, SP, Brasil. ORCID: http://orcid.org/0000-0003-3657-9379. E-mail: mvirginiaurso@gmail.com (corresponding author)

${ }^{4}$ ORCID: http://orcid.org/0000-0002-4031-3146. E-mail: eaospinap@unal.edu.co

${ }^{5}$ ORCID: http://orcid.org/0000-0002-6143-9821. E-mail: fjsernac@unal.edu.co

\begin{abstract}
A new species of Brethesiamyia (Diptera: Cecidomyiidae) is described from Colombia, which represents the first record of the genus for the country. We described the species based on male, female, pupa, larva of third instar and gall morphology, which the larva induces on leaves of Myrcia sp. (Myrtaceae) from the foothills situated at the connection of the Andes and the Amazon basin from Colombia. The first description of the third larval instar is provided for the genus.
\end{abstract}

Key-Words. Asphondyliini; Gall makers; Myrtaceae; Neotropical; Schizomyiina.

\section{INTRODUCTION}

The genus Brethesiamyia Maia belongs to Schizomyiina (Diptera, Cecidomyiidae), a subtribe with worldwide distribution, of which the largest richness is found in the neotropics, where 19 of the 28 valid genera are distributed endemically (Gagné \& Jaschhof, 2017). Genera of Schizomyiina are characterized by the larva with ventral anus and the gonostylus tooth unfused (Tokuda, 2012). The only representative of the subtribe in Colombia is Schizomyia manihoti Tavares, associated with Manihot utilissima Pohl. (Euphorbiaceae). Brethesiamyia is a monotypic genus of cecidomyiid that induces leaf galls on Myrcia retorta Cambess (Myrtaceae) in Brazil (Maia et al., 2009). Larval forms of Brethesiamyia are unknown.

Myrcia is the fourth largest genus of Myrtaceae, containing around 800 species. Its distribution is exclusively Neotropical with the highest species diversity in the Amazon and the Caribbean but is even higher in the Brazilian Cerrado and the Atlantic forest biomes (Lucas et al., 2018). There are 392 known species in Brazil (Flora do Brasil 2020, 2020) and 28 in Colombia (Parra-O. et al., 2018). No one of the 45 species in 21 genera of gall maker insects distributed in Colombia was found inducing galls in species of Myrtaceae.

In this paper, we describe the second known species of the genus Brethesiamyia from the Neotropical region also galler in leaves of a Myrcia species, the first one from Colombia, as well as the first description of the third larval instar of the genus.

\section{MATERIAL AND METHODS}

Branches of the host plant were collected in a rainforest vegetation of the AndeanAmazonian Piedmont in the Amazonian Research Center Macagual, Department of Caquetá, Colombia (Geographic coordinates, 1N 30'01,91"; 75W 39'49,56", 247 m altitude), on date 27-III-2018.

The branches with galls were placed into several labeled plastic bags and transferred to the laboratory. In the laboratory, some galls were maintained in the plastic bags until the emergence of the adults and some were dissected to obtain the immature forms. All specimens obtained from rearing were conserved in $80 \%$ alcohol for slide mounting. The study followed the adult morphology terminology of Gagné (2018) while the 
immature terminology and the slide mounting method were based on Gagné (1994). Electron microscope images were taken with a FEI/THERMO Quanta 650 FEG available at Laboratório Nacional de Nanotecnologia (LNNano), in the Centro Nacional de Pesquisa em Energia e Materiais (CNPEM), Campinas. The holotype was deposited in the Entomological Museum Universidad Nacional Agronomía Bogotá (UNAB) following the curatorial standards of Martínez-Alava \& Serna (2015). The paratypes were deposited in the Diptera Collection of the Museu de Zoologia da Universidade de São Paulo (MZUSP). Type specimens of Brethesiamyia myrciae Maia from Museu Nacional do Rio de Janeiro (MNRJ) were examined for comparison.

\section{RESULTS}

\section{Taxonomy}

\section{Cecidomyiidae Newman, 1834 Asphondyliini Gagné, 1994 Genus Brethesiamyia Maia}

Brethesia Maia in Maia et al., 2009: 38, preocc. Schrottky, 1909. Type species, Brethesia myrciae Maia (orig. des.). Brethesiamyia Maia, 2010: 146, new replacement name for Brethesia Maia, 2009.

Diagnosis: Female flagellomeres 9-12 progressively shortened; female circumfila reticulate; palpus one-segmented; first tarsomeres without pointed ventroapical extension; empodia much shorter than claws; claws similar on all legs; tooth of gonostylus denticulate; parameres [= mesobasal lobes sensu Gagné, 2018] present; aedeagus bulbous; female abdominal tergite 8 without cercilike lobes; female abdominal segment 9 short, pliable, with long setae; pupal antennal horns short (Maia et al., 2009).

Addition to the diagnosis: Pupal cephalic setae absent.

Description of $3^{\text {rd }}$ instar larva: Spatula with two triangular and tapered apical teeth; long shaft strongly sclerotized and posterior region enlarged; one lateral papilla setose on each side of spatula; terminal segment without papillae; ventral anus rounded (Figs. 3C, 3D).

\section{Brethesiamyia colombiana Ospina \& Urso-Guimarães sp. nov.} (Figs. 1-4)

Description: Adult: Body length $1.67 \mathrm{~mm}$ in male $(n=2), 2.06 \mathrm{~mm}$ in female $(n=2)$. Head (Fig. 1A): eyes black, holoptic, facets circular, closely adjacent. Antenna: Length $1.02 \mathrm{~mm}$ in male $(\mathrm{n}=2)$ and $1.08 \mathrm{~mm}$ in female $(n=2)$; scape broader distally, length $0.05 \mathrm{~mm}(\mathrm{n}=4)$ and pedicel globose, length $0.05 \mathrm{~mm}(\mathrm{n}=4)$ in both sexes; flagellomeres cylindrical, circumfila of each flagellomere completely reticulated in both sexes (Figs. 1B-D), flagellomeres 1-2 connate; flagellomere 12 cylindrical in males, ovoid in females ( $n=4)$ (Figs. 1C, 1E). Frontoclypeus with 12 setae in males $(n=2)$ and 13-14 in females $(n=2)$. Labrum triangular, short-attenuate. Hypopharynx of same shape as labrum. Labella elongate-convex, each with 5-9 long lateral setae and 2 short medial sensory setae. Palpus total length $0.03 \mathrm{~mm}(\mathrm{n}=4)$, palpus 1-segmented. Thorax: Scutum and scutellum brown. Anepimeron with $12-18$ setae $(n=3)$, other pleural sclerites bare. Legs: Tarsal claws simple, bent beyond midlength, empodium rudimentary (Fig. 1F). Wings (Fig. 1G): $1.48 \mathrm{~mm}$ long from arculus to apex, and $0.64 \mathrm{~mm}$ wide in male $(n=2)$; and $2.05 \mathrm{~mm}$ long and $0.90 \mathrm{~mm}$ wide in female $(n=8)$.

Male abdomen (Fig. 2A): Tergites 1-7 rectangular, with a complete row of posterior setae and elsewhere with several scattered setae; tergite 8 not sclerotized and bare, trichoid sensilla absent in all tergites. Sternites 2-7 rectangular, setae more abundant anteriorly and medially; sternite 8 not sclerotized and bare, trichoid sensilla absent in all sternites. Female abdomen (Fig. 2B): Tergites 1-7 as in male; tergite 8 not sclerotized, with row of posterior setae; trichoid sensilla absent in all tergites. Sternites 2-6 as in male; sternite 7 with scattered setae and well sclerotized area on posterior margin; sternite 8 not sclerotized with ventral spinules, trichoid sensilla absent in all sternites. Male terminalia (Fig. 2C): Gonocoxites wide and setose; mediobasal lobe truncated apically with apical setae; gonostylus rectangular with few setae, gonostylus bearing spines fused, covered with a row of strong distal setae, $0.04 \mathrm{~mm}$ long and $0.03 \mathrm{~mm}$ wide $(\mathrm{n}=2)$; cerci triangular with both setae and microtrichiae; hypoproct weakly bilobed, with setulae and two strong setae at apex of each lobe; lobes rounded apically; aedeagus glossiform. Ovipositor (Fig. 2D): 0.12-0.16 mm long (from basal margin of segment 9 to cerci apex) $(n=4)$, sternite 7 about twice longer than protrusible portion; elongated, slightly protractible, ventrally striated, several long dorsally setae, sparse ventral setae; cerci tiny and partially fused at apex (Fig. 2E).

Pupa: Light brown. Length 2.26-3.00 $\mathrm{mm}(\mathrm{n}=2)$. Head (Fig. 3A): Antennal horn $0.17 \mathrm{~mm}$ long $(\mathrm{n}=4)$ (from antennal base to apex), triangular, single pointed, sclerotized edges with convergent apex; cephalic setae absent; lower and lateral papillae absent; upper facial margin thickened and sclerotized. Thorax: Prothoracic spiracle short $0.03 \mathrm{~mm}$ long $(\mathrm{n}=2)$ weakly sclerotized and digitiform. Abdomen: Abdominal tergites 2-8 covered with tiny spines; tergites 2-8 with a pair of dorsal papillae and a pair of dorso-lateral discrete abdominal spiracles; terminal segment rounded (Fig. 3B).

Larva $3^{\text {rd }}$ instar: Yellowish, fusiform. Body: $1.58 \mathrm{~mm}$ long $(n=4)$. Spatula (Fig. 3C) with 2 triangular and tapered anterior teeth, with a long and strongly sclerotized stalk in the upper and middle region, and posterior region enlarged, $0.15 \mathrm{~mm}$ long $(\mathrm{n}=4)$; one lateral papilla setose 
on each side of the spatula. Terminal segment without papillae, ventral anus rounded (Fig. 3D).

Etymology: The specific name, "colombiana", is a feminine name in apposition referred to people born in Colombia, the type-locality of the new species.

Gall and biology (Fig. 4A): Galls are cylindrical, $6.1 \mathrm{~mm}$ long, tapered to the apex greenish with white or brown pubescence densely distributed on the apex of the gall, apex brownish, unilocular, and distributed in groups on the midrib of adaxial. Pupation occurs in the gall. The adults emerged through a hole in the apex of the galls (Fig. 4B).

\section{EXAMINED MATERIAL}

Holotype, male, Colombia, Caquetá, Florencia, Vereda La Viciosa, Centro de Investigaciones Amazónicas Macagual (CIMAZ), 01³0'01,91"N, 75³9'49,56"W, 27-III-2018, 247 m), Esau Ospina leg., slide mounted deposited in UNAB, catalog number 6000. Paratypes, 1 male, 4 females, 2 pupal exuviae, 4 larvae, same locality, date and collector as holotype, slide mounted deposited in MZUSP.

Additional material: 12 males, 2 females, 1 larva same locality, date and collector as holotype, ethanol pre-

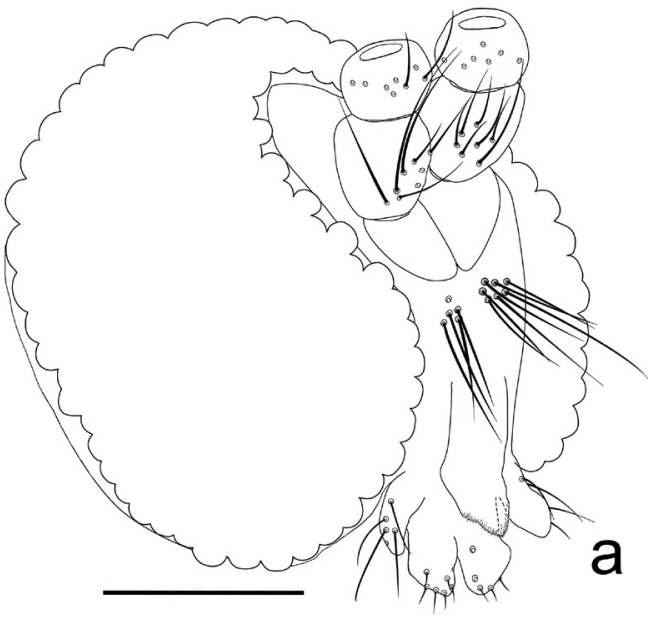

$0.1 \mathrm{~mm}$

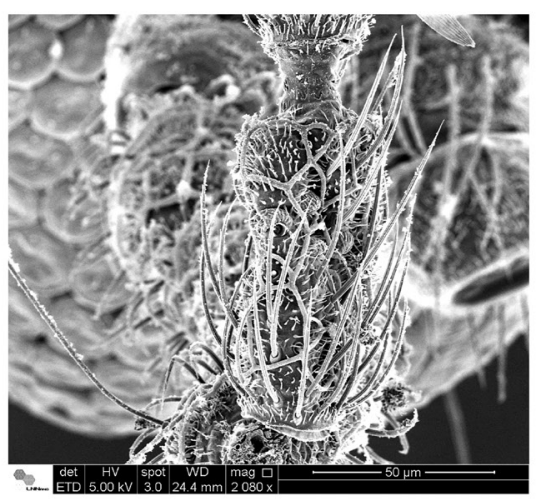

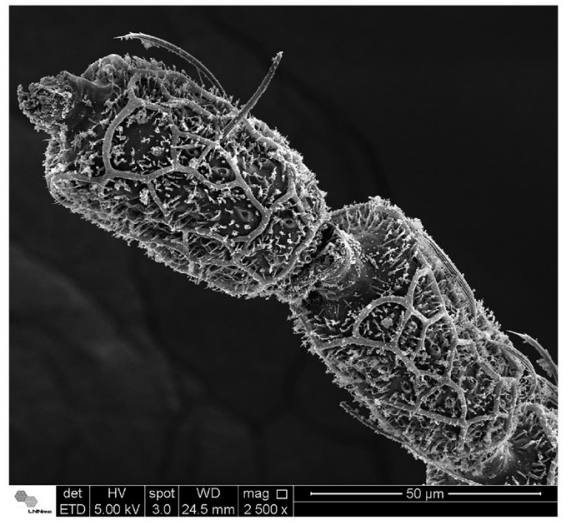

b

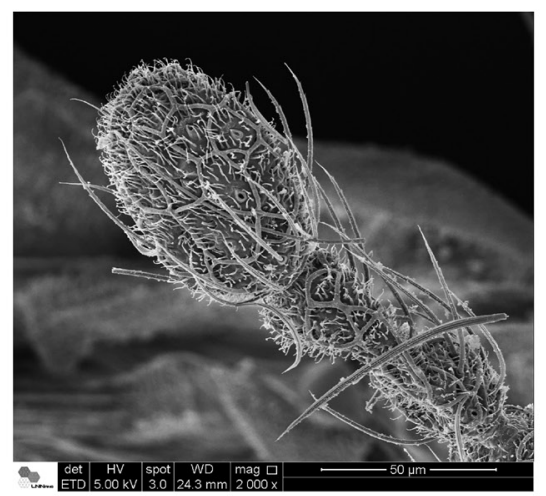

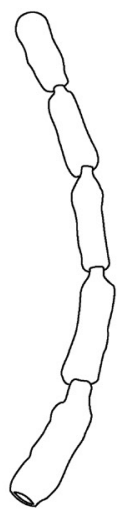

C

$0.04 \mathrm{~mm}$

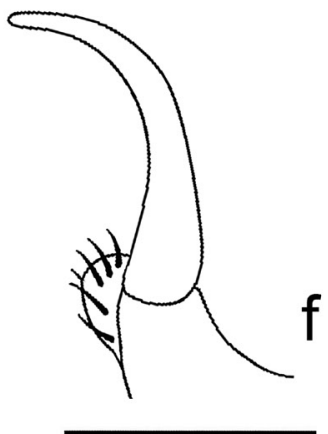

$0.02 \mathrm{~mm}$

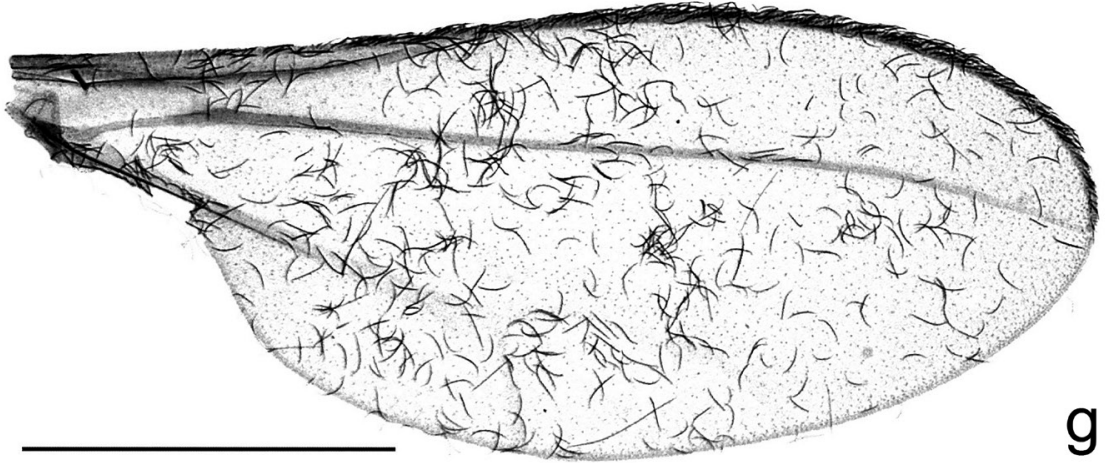

$0.5 \mathrm{~mm}$

Figure 1. Brethesiamyia colombiana Ospina \& Urso-Guimarães, sp. nov. (A) Male head, latero-frontal view; (B) Male flagellomeres 5-6; (C) Male flagellomeres 8-12; (D) Female flagellomere 5; (E) Female flagellomeres 10-12; (F) Male foreleg tarsal claw and empodium; (G) Male wing. 

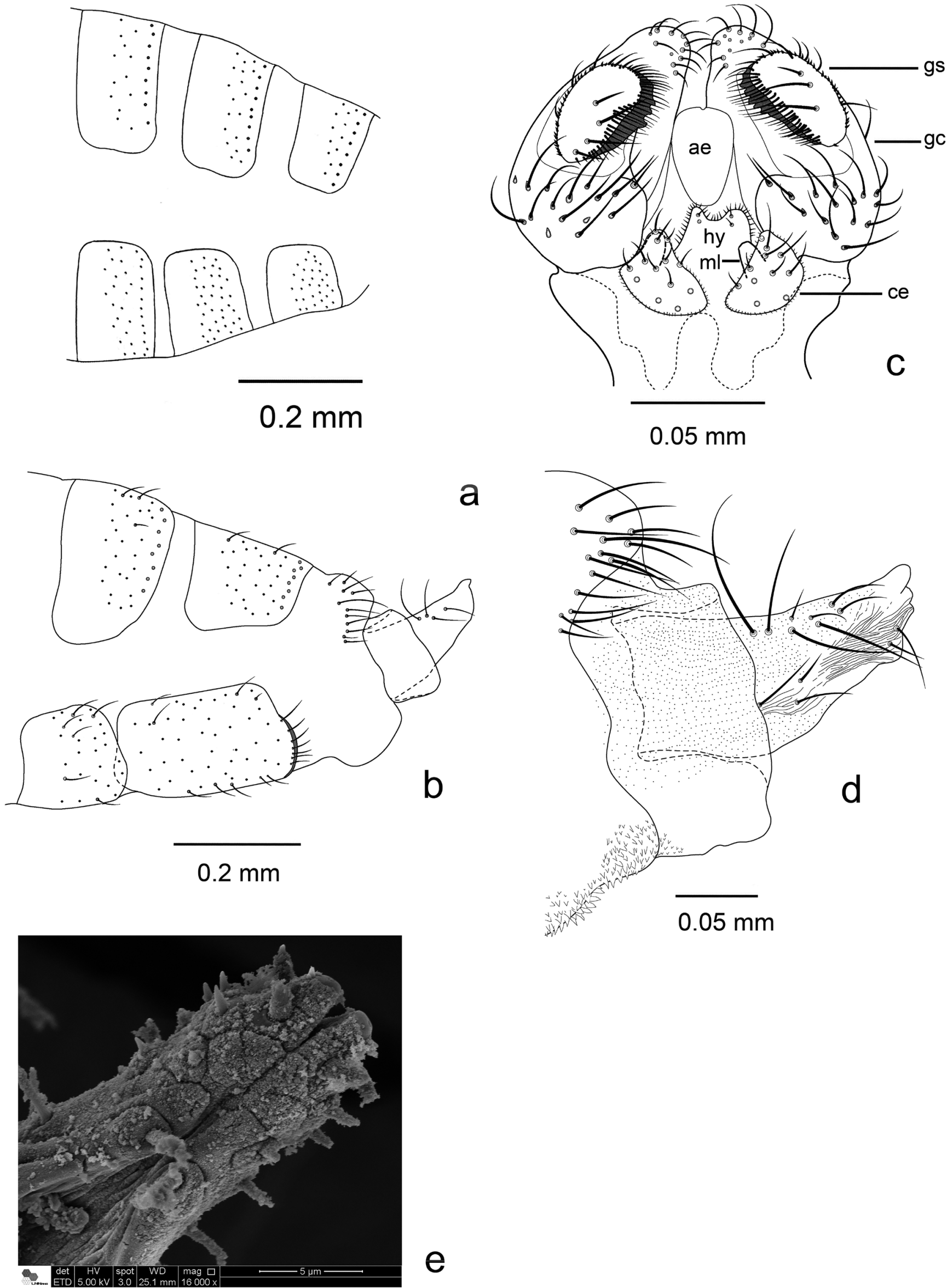

e

Figure 2. Brethesiamyia colombiana 0spina \& Urso-Guimarães, sp. nov. (A) Male abdominal segments 5-7, lateral view; (B) Female abdominal segments 6-8 and ovipositor, lateral view; (C) Male terminalia, dorsal view; (D) Ovipositor, lateral view; (E) Female cerci, ventral view. Abbreviation: ae, aedeagus; ce, cercus; gc, gonocoxite; gs, gonostylus; hy, hypoproct; ml, mediobasal lobe. 

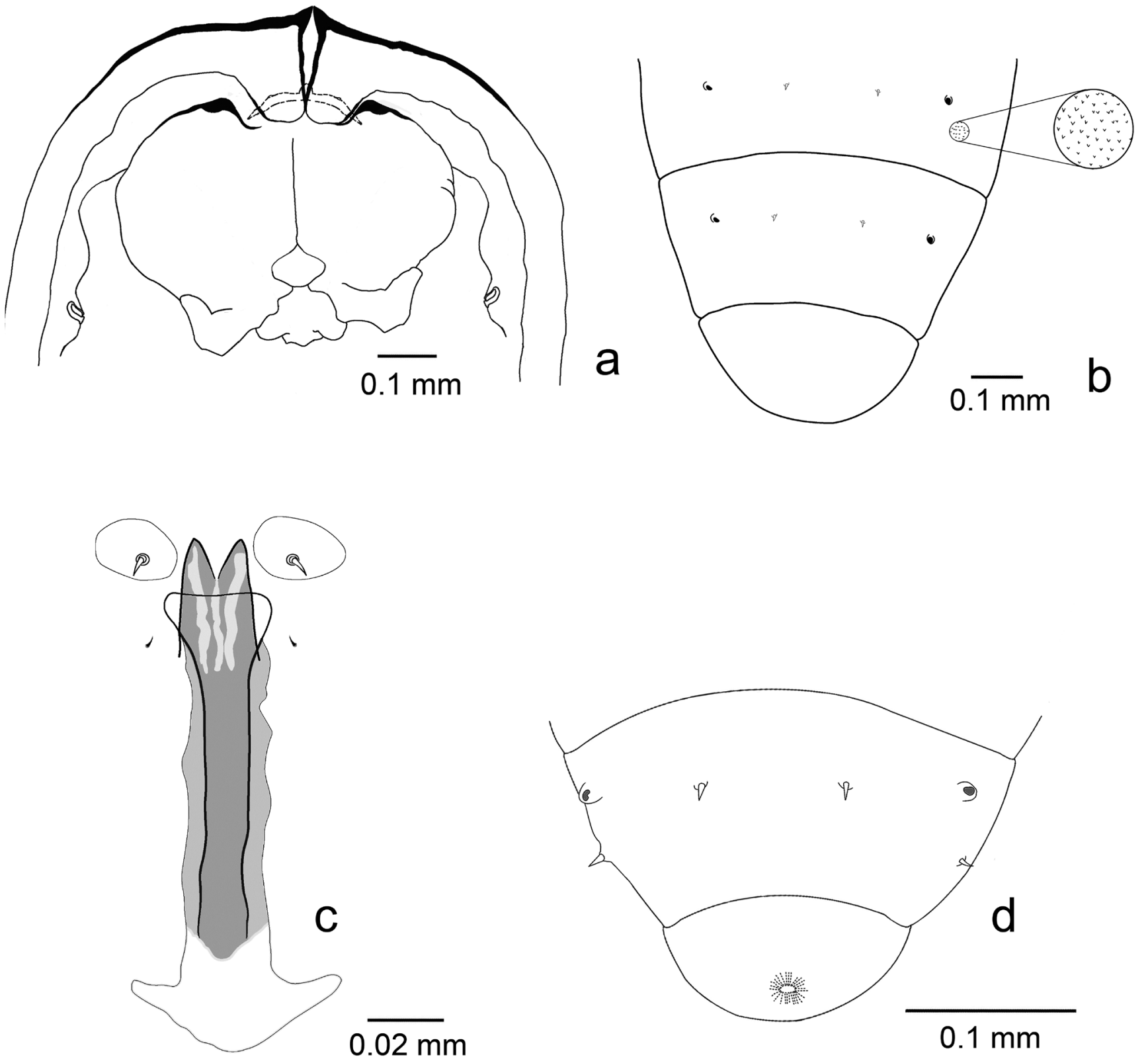

Figure 3. Brethesiamyia colombiana 0spina \& Urso-Guimarães, sp. nov. (A) Pupal head and $1^{\text {st }}$ thoracic segment, frontal view; (B) Pupal terminal segments, dorsal view; (C) Larval prothoracic spatula and the associated papillae, ventral view; (D) Larval terminal segments, dorsal view.

served, in the Entomological Museum UNAB, catalog number 6000.

Remarks: In the original description of Brethesiamyia, Maia et al. (2009) highlighted its similarities with the genera Stephomyia Tavares and Bruggmannia Tavares, although pointing out that Brethesiamyia have distinctive characters, especially on ovipositor. In Brethesiamyia, the ovipositor is longer than in Stephomyia, and the cerci are separated apically (Fig. 2D), whereas fused in Bruggmannia. The adults of all collected specimens of the new species of Brethesiamyia presented these distinctive characters. In B. myrciae, female antennal flagellomeres have circumfila incompletely reticulated, sternite 7 about 1.2 longer than the protrusible portion of ovipositor; cerci reniform and hypoproct deeply bilobed in males, pupa with antennal horn bifid; and induces tear-shaped gall. The adults of $B$. colombiana sp. nov. have flagellomeres completely reticulated in the female antennae, sternite 7 about twice longer than protrusible portion of ovipositor; cerci triangular and hypoproct weakly bilobed in males, and pupa with antennal horns triangular, single pointed and 4,25 longer than in B. myrciae; and induces cylindrical galls. Third larval instar is herein described for the first time, and the absence of cephalic setae was added to the diagnosis of the genus.

\section{DISCUSSION}

Both species of Brethesiamyia induce leaf galls on species of Myrcia, one of the richest plant genera of the Brazilian (Flora do Brasil 2020, 2020) and Colombian flora (Parra-O. et al., 2018). Based on the morphological characters of the host plant of $B$. colombiana sp. nov., it can be regarded as belonging to the genus Myrcia, probably M. canalicula- 

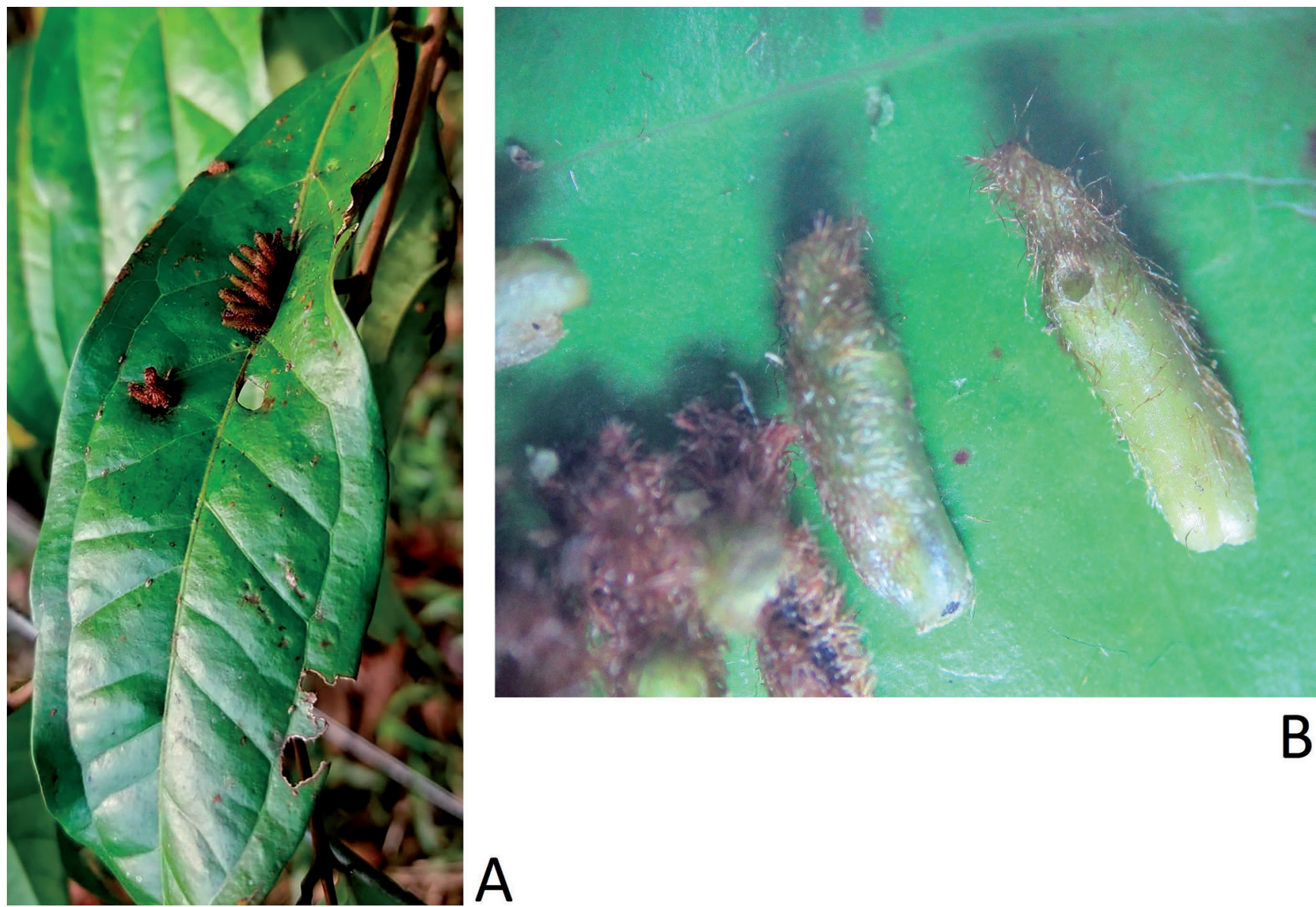

B

Figure 4. Galls on leaf of Myrcia sp. (A) Leaf galls induced by Brethesiamyia colombiana Ospina \& Urso-Guimarães, sp. nov.; (B) gall detail with scape hole.

ta (McVaugh) A.R.Lourenço or M. cuspidata (Mart. ex DC.) A.R.Lourenço \&E. Lucas, both distributed in Acre, Amazonas and Rondônia, Brazil. Myrcia retorta, the other host plant associated with Brethesiamyia, is distributed Southeastern and Southern Brazil (Sobral et al., 2010). The disjunction of the distribution observed for the Brethesiamyia species along with the wide distribution of the genus of the host plant in Neotropical region, particularly in South America, suggests that the genus could be much more diverse and present in different types of biomes in the Neotropical Region than it was previously known.

\section{ACKNOWLEDGEMENTS}

The authors would like to thank the Entomological Museum UNAB for providing the necessary tools for the collecting and rearing specimens for the curatorial process; MSc. Thiago B. Flores (UNICAMP) for the host plant identification; and the Laboratório Nacional de Nanotecnologia (LNNano) in the Centro Nacional de Pesquisa em Energia e Materiais (CNPEM). for technical support during electron microscopy work. This research was supported by the Colombian Ministery of Sciences (Minciencias) under the project "Reconocimiento de insectos de importancia agronomica asociados al agroecosistema Cacaotero de la Amazonia Colombiana", code 110171250625 CT FP44842-128-2016.

\section{AUTHORS' CONTRIBUTIONS}

EAOP performed the fieldwork and preparation of samples; MVUG made the photomicrographic documentation; FJSC provided access the facilities at Entomological Museum UNAB; EAOP and MVUG performed morphological studies of specimens; MVUG, CJEL and FJSC helped supervise the project. All authors discussed the results and contributed to the final manuscript.

\section{REFERENCES}

Flora do Brasil 2020. 2020. Lista de espécies da flora do Brasil. Rio de Janeiro, Jardim Botânico do Rio de Janeiro. Available: http://floradobrasil.jbrj. gov.br. Access: 07/2020.

Gagné, R.J. 1994. The gall midges of the Neotropical region. Ithaca, Cornell University Press.

Gagné, R.J. 2018. Key to adults of North American genera of the subfamily Cecidomyiinae (Diptera: Cecidomyiidae). Zootaxa, 4392(3): 401-457.

Gagné,R.J.\&Jaschhof,M.2017.A catalogofthe Cecidomyiidae(Diptera) oftheworld. 4.ed. Digital. Available: https://www.ars.usda.gov/ARSUserFiles/80420580/ Gagne 2017 World Cat 4th ed.pdf. Access: 07/2020.

Lucas, E.J.; Amorim, B.S.; Lima, D.F.; Lima-Lourenço, A.R.; Lughadha, E.M.N.; Proença, C.E.B.; Rosa, P.O.; Rosário, A.S.; Santos, L.L.; Santos, M.F.; Souza, M.C.; Staggemeier, V.G.; Vasconcelos, T.N.C. \& Sobral, M. 2018. A new infra-generic classification of the species-rich Neotropical genus Myrcia s.l. Kew Bulletin, 73: 1-12. 
Maia, V.C. 2010. Um novo nome para Brethesia Maia (Diptera, Cecidomyiidae). Revista Brasileira de Entomologia, 54(1): 146.

Maia, V.C.; Fernandes, G.W. \& Negreiros, D. 2009. A new genus and species of gall midge (Diptera: Cecidomyiidae) associated with Myrcia retorta (Myrtaceae). Revista Brasileira de Entomologia, 53(1): 38-40.

Martínez-Alava, J. \& Serna, F. 2015. Managing insect collections. Micropezidae (Diptera: Nerioidea) of the Entomological Museum UNAB. Agronomia Colombiana, 33: 339-347. D0I

Parra-0., C.; Patiño, A.; Martínez, M. \& Suárez, M. 2018. Novedades taxonómicas en Myrtaceae para Colombia. Caldasia, 40(1): 91-96.
Schrottky, C. 1909. Himenópteros de Catamarca. Annales de la Sociedad Científica Argentina, 68: 233-272.

Sobral, M.; Proença, C.; Souza, M.; Mazine, F. \& Lucas, E. 2010. Myrtaceae In: Forzza, R.C. et al. (Eds.). Lista de espécies da flora do Brasil. Rio de Janeiro, Jardim Botânico do Rio de Janeiro. Available: http://floradobrasil.jbrj. gov.br. Access: 07/2020.

Tokuda, M. 2012. Biology of Asphondyliini (Diptera: Cecidomyiidae). Entomological Science, 15: 361-383. 